\title{
INWARD AND OUTWARD FDI IN LITHUANIA AND ESTONIA: REVIEW OF PATTERNS IN NEIGHBORING COUNTRIES
}

\author{
Romualdas Ginevičius ${ }^{1}$, Manuela Tvaronavičienė $\dot{2}^{2}$ \\ ${ }^{1}$ Vilnius Gediminas Technical University, Sauletekio al. 11, LT-10223 Vilnius, Lithuania, Phone: +370 52744862; \\ Fax:+370 52744861,E-mail: rector@adm.vtu.lt \\ ${ }^{2}$ Vilnius Gediminas Technical University, Saulètekio al. 11, LT-10223 Vilnius, Lithuania, Phone: +370 52744862; \\ Fax: +370 52744861,E-mail: manuela@vv.vtu.lt \\ Received 0209 2005; accepted 23092005
}

\begin{abstract}
The paper aims to trace how important state policies, cultural differences and neighborhood of developed countries are as driving forces attracting foreign capital inflows. Authors overview the inward and outward foreign direct investment (FDI) tendencies in Lithuania and Estonia, reveal similarities and differences of the neighbor countries. Authors distinguish and discuss a role of privatization policy in attracting foreign direct investments. The assumption about different inward FDI sources caused by different privatization strategies adopted by considered countries is to be elaborated. Another focus of presented paper is outward FDI structure in terms of capital origin, and differences of its in scale in two Baltic countries - Lithuania and Estonia. Phenomenon of Scandinavian FDI channeling through Estonia is to be traced and interpreted.
\end{abstract}

Keywords: inward, outward foreign direct investments (FDI), Lithuania, Estonia.

\section{Introduction}

Post - socialist economies have in general low levels of domestic savings due to their low levels of incomes. The foreign direct investment (FDI) is seen as an important potential contribution to the process of restructuring, economic growth and development of technology in these countries.

Baltic States have adopted rather favorable laws for foreign investors. They have emphasized the importance of attracting foreign capital and have tried to create favorable investment environment through appropriate tax concessions. New markets, lower production costs and higher profit rates have been the main motivators in investing into transition countries. Privatization programs of some of these countries have also facilitated foreign direct investments.

The object of this paper work is to overview the inward and outward foreign direct investment tendencies in Lithuania and Estonia by exploring the main determinants, influencing development of FDI in those two Baltic countries.

\section{Foreign direct investment in Lithuania and Estonia}

\section{1. Case of Lithuania}

After regaining the independence, Lithuania attempted to recover from the command economy of the former Soviet Union. The country faced major problems such as: huge inflation (mainly due to considerably increased costs of raw materials and other resources from Russia), reduction in GDP caused by the change in economic style and loss of previous economic relations. Gross domestic and foreign investment fell in line with economic performance in the early 1990s. It was hard for the Lithuanian Government to subsidize the big inefficient manufacturers without the involvement of the Soviet Union. Thus, drastic measures of privatization had to be taken, changing the balance between government investment and private sector investment.

As laws for investments were created, mass privatization started. Investments were growing strongly, exceeding LTL 10 billion for the first time 
in 1997. However, the downturn of late 1998 and 1999, caused mostly by the Russian financial crisis, made investors more skeptical and investments started to decrease. The negative trend continued for more than two years, until mid-2000. Gross investments started to rise again in 2001, being mainly determined by GDP increase due to growing private and government consumption. Along with improving investment climate in the country, there is also a rise in foreign direct investments since 2001 (Fig. 1).

In 2002, gross investments reached LTL 11.4 billion and foreign direct investments (FDI) - LTL 2.6 billion. (Lithuanian Department of Statistics).

Foreign investments play an important role in transition economies. FDI inflows to Lithuania were rather low in the beginning of $1990 \mathrm{~s}$, but started to increase in the mid-90s and peaked in 1998, reaching LTL 3.7 billion. The peak was caused mostly by the privatization of local telecommunication monopoly Lietuvos Telekomas.

In the early 1990s, the majority of FDI was related to the privatization process, but since the second half of the 1990s, foreign direct investments have also been increasing as the investors expanded their operations in the country.

Opinion prevail that main motives attracting foreign companies are cheap and skilled work force, potentially growing market and geographic location. On the other hand, bureaucratic difficulties and unstable legislative base are found to be among the most significant barriers to investment activities (Advantage Lithuania, Lithuanian development agency).

In the beginning of the 1990s, the USA dominated the direct investment inflows into Lithuania, until Sweden became the largest investing country in 1999. As of 1 January 2003, Denmark represented $17.25 \%$ of cumulative FDI followed by Sweden (15.3\%) and Estonia (11.7\%). In 2004, the dominating country remains Denmark (15.8\%), Sweden remains mostly the same and the third becomes Germany (9.6\%). In general, the importance of the EU countries as investors in the country is constantly growing. The recent tendencies are presented in Figure 2.

Biggest part of foreign direct investments is put in manufacturing sector. Also foreign investors are interested in trade, communication services and financial intermediation sectors (Table 1).

\subsection{Case of Estonia}

Since independence in 1991, the encouragement of foreign direct investment (FDI) has been one of the

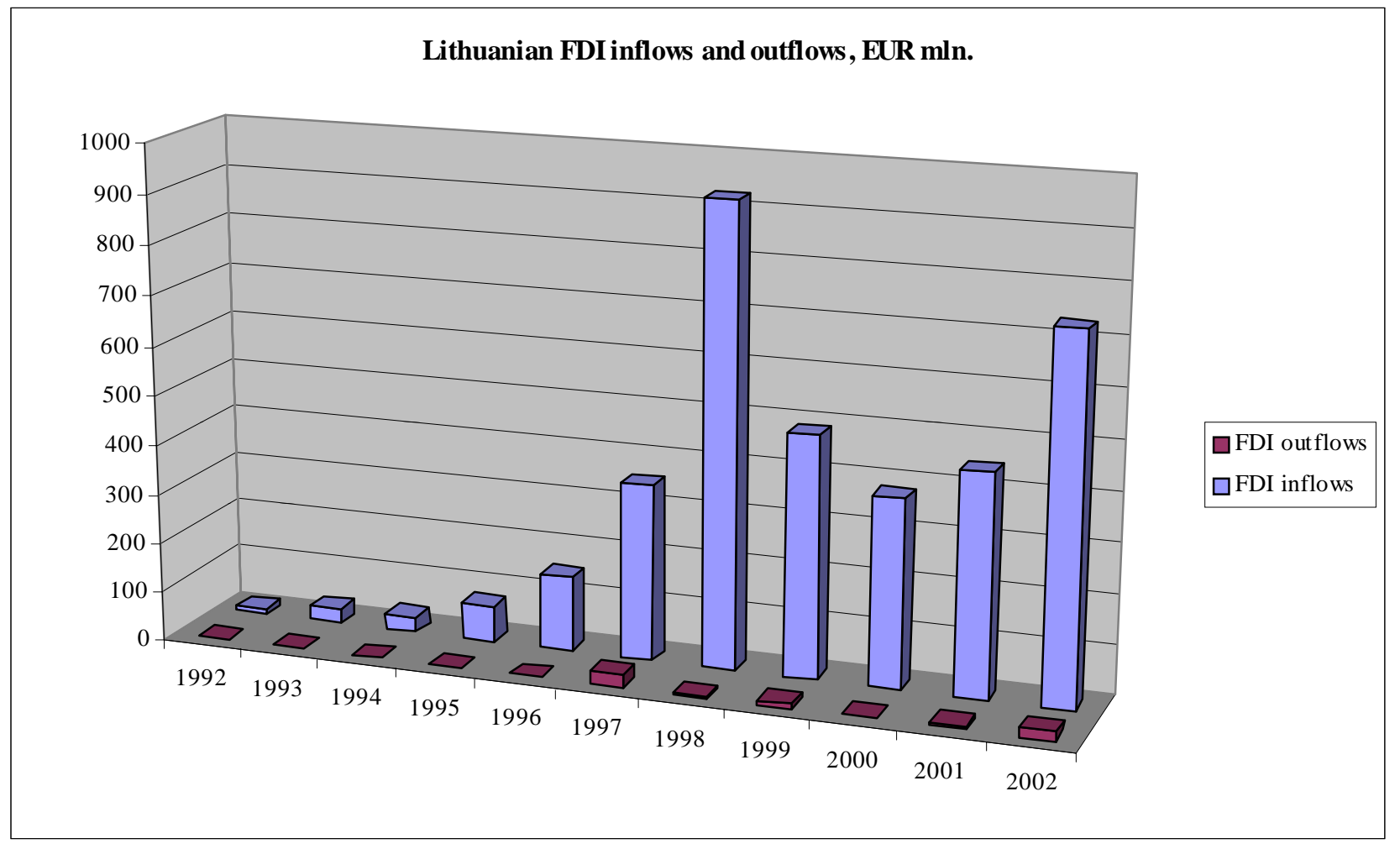

Figure 1. Lithuanian FDI inflows and outflows 1992-2002 (Lithuanian Department of Statistics) 


\section{Cumulative FDI by Country as of October 1, 2004} (\% of total)

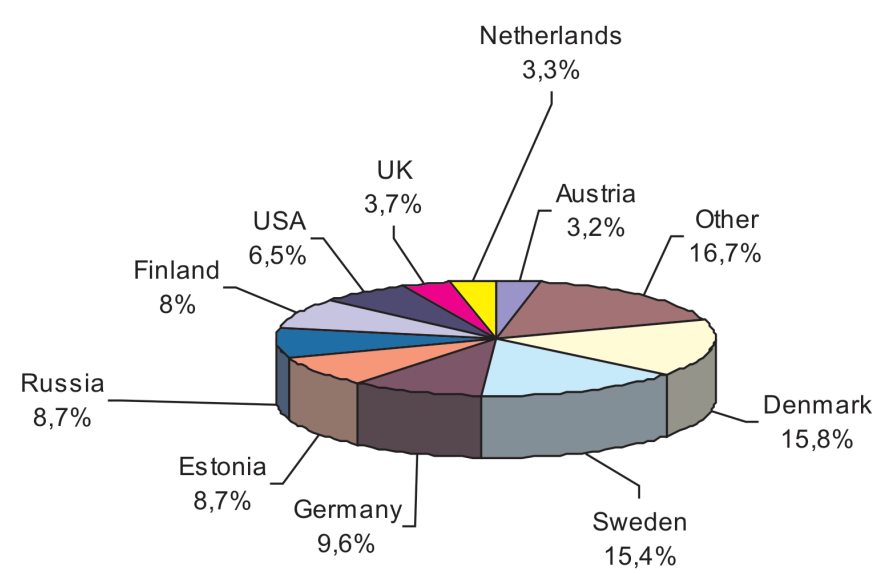

Figure 2. Cumulative FDI in Lithuania by country (Lithuanian Department of Statistics)

Table 1. FDI by sectors October 1, 2004 (Lithuanian Department of Statistics)

\begin{tabular}{|l|l|l|}
\hline Sector & $\begin{array}{l}\text { Sum } \\
(€ \text { million })\end{array}$ & $\begin{array}{l}\% \text { of total } \\
\text { sum }\end{array}$ \\
\hline Manufacturing & 1,470 & $33.9 \%$ \\
\hline Trade & 741 & $17.1 \%$ \\
\hline Financial intermediation & 668 & $15.4 \%$ \\
\hline Communication services & 665 & $15.3 \%$ \\
\hline Other & 793 & $18.3 \%$ \\
\hline
\end{tabular}

priorities in Estonian economic development policy. This is reflected in the elaboration of laws on ownership reform, foreign investment, privatization, the creation of special incentive programs and the adaptation of regulatory frameworks to meet internationally agreed standards. During the privatization process the focal aim was to attract strategic investors who would take vested interest in Estonian companies, thus helping to speed up the restructuring process. This policy has more or less yielded expected returns. Numerous successful foreign ownerships, especially in small and middle scale enterprises, have considerably improved the economic conditions despite the 1998s economic downturn related with stock market crash because of Russian crisis. As a result FDI, inflows have grown so that the total stock reached EEK 44.5 billion by the end of 2000. This represented a growth in per capita terms from EEK 7000 in 1996 to EEK 32600 by the end of 2000, making it one of the highest accumulated FDI levels per capita in Central and Eastern Europe.
Estonia is generally viewed as having very few restrictions on foreign investments, offering high levels of freedom to foreign investors and the protection of property rights. Throughout the 1990s, foreign investors and their investments were granted 'equal rights and obligations' with their domestic counterparts, with freedom to repatriate profits, dividends and invested capital.

Since, 1994, the Estonian Investment Agency has promoted foreign direct investment to Estonia by raising awareness of investment opportunities, facilitating contacts with the public and private sectors and supplying foreign investors with information and assistance in the initial establishment phase. Estonia's future FDI policies include seeking to attract more investment and continuing to adapt regulatory and institutional process to meet internationally accepted standards.

The yearly inflows of FDI have grown considerably during the 1990s, peaking in 1998. At the same time, the outflow of FDI has also increased, particularly in recent years (Fig. 3). This is associated with the increasing activities of Estonian investors abroad (particularly in Estonia's Baltic neighbors) and the growing presence of large international investors in Estonia, which have invested in the other Baltic countries through their Estonian subsidiaries (United Nations).

Foreign investors have been and will be in the focus of Estonian economic policy. They have played considerable role in achieving the present economic status and living standard.

The main driving forces FDI in Estonia are supposed to be potential market growth, financial and political stability. Production costs in Estonia are lower than in Central European transition countries, but this advantage is cancelled by transportation costs in the servicing markets of the developed Western European countries. At the same time, Estonia has higher production costs than Latvia, Lithuania and Russia.

In the beginning of the transition period FDI flows into Estonia were mainly caused by the privatization process. In Estonia the privatization process was nearly completed in the end of 1995. Now special attention is being paid to reducing bureaucracy and regulation further. Very few restrictions to FDI remain. Estonia now faces the challenge of keeping up with the competition and catching up with the richer nations. A significant part of the FDI came from Sweden (42.8\%) and Finland (27.0\%) (Figure 4).

The main sectors in which inward investment is 


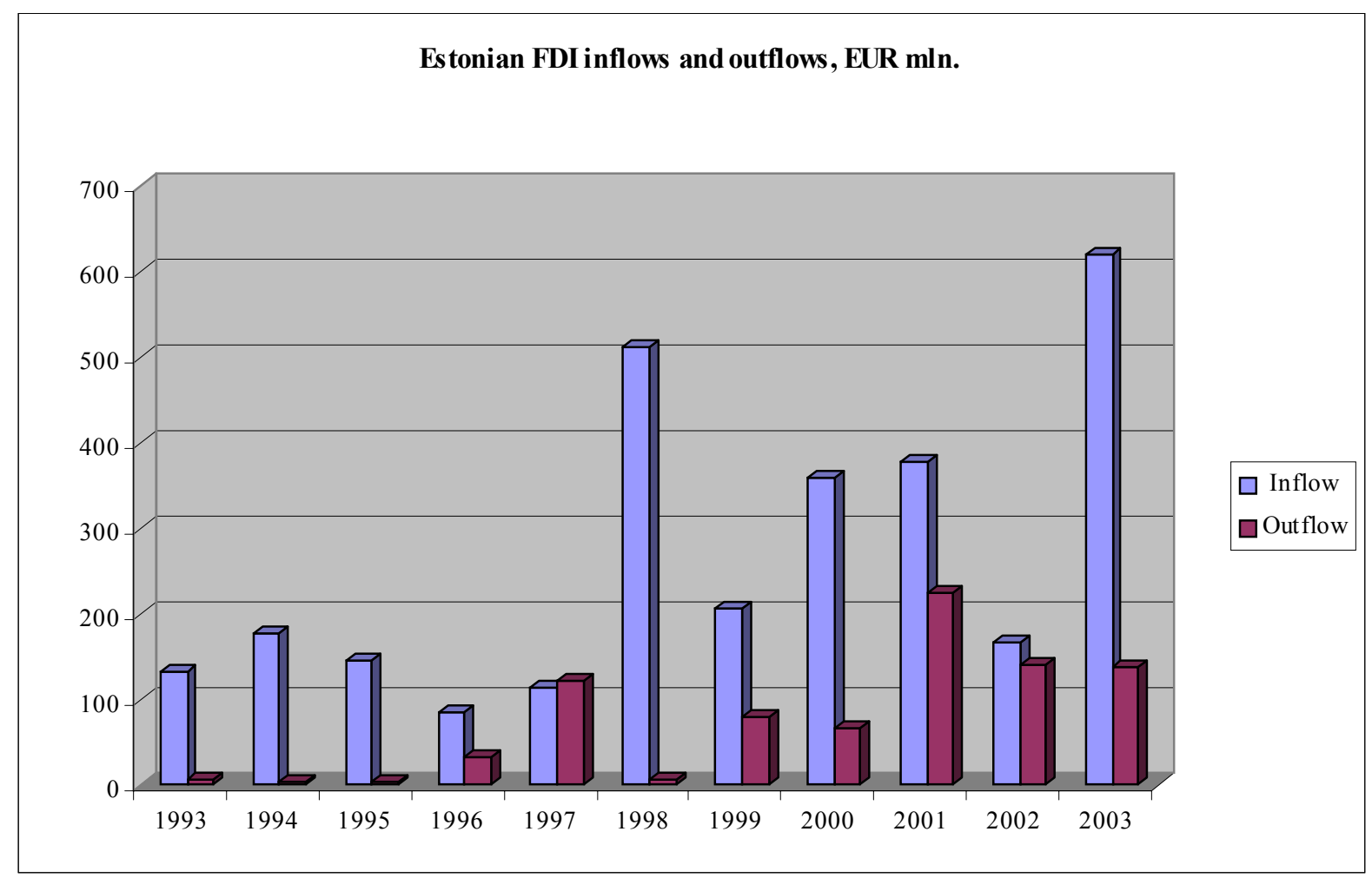

Figure 3. Estonian FDI inflows and outflows, 1993-2003 (Kivits K., Purju A., 2003)

Cumulative FDI in Estonia by countries, 2004 (\% of total)

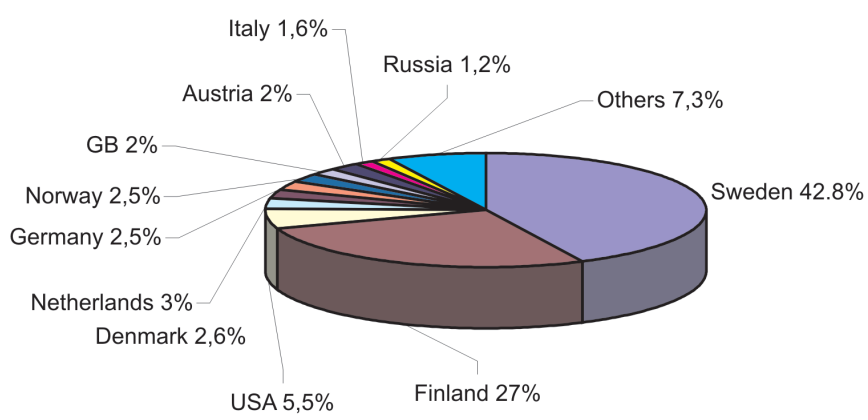

Figure 4. FDI in Estonia by countries, 2004 (Bank of Estonia)

concentrated are banking and financial services (29.8\%), which is explained by the strong presence of Nordic banks in Estonia (Table 2).

The high level of FDI in telecommunications followed privatization and the liberalization of the industry. Within the manufacturing sectors, food and beverages occupy first place, followed by wood, publishing and printing, textiles and clothing. Electronics has also seen an increase in FDI, as Finnish subcontractors have established in Estonia, working for the multinational leaders in the industry.
Table 2. FDI by sectors January 1, 2004 (Bank of Estonia)

\begin{tabular}{|l|c|c|}
\hline Sector & Sum (€ million) & $\%$ of total sum \\
\hline Manufacturing & 930 & $18,1 \%$ \\
\hline Trade & 782,6 & $15.3 \%$ \\
\hline Financial intermediation & 1528,7 & $29,8 \%$ \\
\hline Communication services & 892 & $17,4 \%$ \\
\hline Other & 996 & $19,4 \%$ \\
\hline
\end{tabular}

\section{Comparing Estonia and Lithuania in terms of FDI}

Lithuania and Estonia are both developing countries that started their transition reforms almost at the same time and from quite similar position. Both countries emphasized the importance of attracting foreign capital and creation of favorable investment environment. After 15 years of independence, formally, conditions for investing are similar; but the situation in these countries is not the same. The main differences are seen in tendencies of inward and outward investments; efficiency of FDI differs as well (Tvaronavičienè M., Kalašinskaitė K., 2003). In the following chapter the influencing factors will be discussed and analyzed. 


\subsection{Inward FDI}

As it was mentioned in previous chapter, the main reason for high FDI level in Lithuania is privatization, as the main investments were made through this process. The privatization of Lithuanian enterprises was carried through two periods. The first period of privatization in Lithuania took place in year 19911995. It was a mass privatization for vouchers with some cash sales. All Lithuanian citizens were theoretically able to participate in the privatization process by purchasing shares of the companies or various investment funds using vouchers or cash. Foreigners could participate with cash offers. At the end of 1995 , over $95 \%$ of construction, agriculture and industry were transferred into private hands. Foreign capital participated in the process (Table 3 ) but the majority of transactions in the first stage of privatization were made by local investors (Lithuanian State Property Fund).

The second period of privatization started in late 1995 when the new law on the privatization of state-owned and municipal property was adopted. This stage lasted until 1999, and had two major differences compared to the first period, as all the property had to be sold in cash under market conditions, and all the investors had equal rights, no matter whether they were local of foreign. Further laws enabling a wider range of privatization methods were accepted in 1997. As a result of the changed legislative framework and recovering economy, considerably more FDI started to flow into the country. (Lithuanian State Property Fund), (Lithuanian Development Agency).

One of the most important privatized objects was the Lithuanian telecommunication monopolist "Lietuvos Telekomas" (Table 4). State received approximately LTL 2040 million for the $60 \%$ stake of the company from the Finnish-Swedish consortium established by Sonera and Telia. Besides the cash receipts generated by the privatization transactions, the state also received a commitment from buyers to invest over one billion litas into the acquired companies over the following years. (Lithuanian State Property Fund), (Lithuanian Business Information Center).

According to the data of privatization agencies, in Lithuania during 1996-1999, 36\% of all FDI was received as a result of privatization.(e.g. in 1999 even of all FDI comprised incomes from Telecom monopoly privatization, what corresponded $-3.9 \%$ of GDP). (Tvaronavičienè M., Ginevičius R. 2003).

In order to evaluate quantitatively relation between these two processes, authors calculated the correlation coefficient between FDI and privatization (Table 5 and

Table 3. The largest investments during the $1^{\text {st }}$ stage of privatization in Lithuania 1991-1995

(Lithuanian Business Information Center)

\begin{tabular}{|l|c|c|c|l|}
\hline Name of enterprise and activity & Privatization \% & $\begin{array}{c}\text { Selling price } \\
\text { LTL, mln. }\end{array}$ & $\begin{array}{c}\text { Investments } \\
\text { LTL, mln. }\end{array}$ & \multicolumn{1}{|c|}{ Investor } \\
\hline Klaipeda Tobacco Factory & 65.5 & 170 & 480 & Philip Morris S.A. \\
\hline Kaunas Confectionery Factory & 67 & 4,8 & 206,4 & $\begin{array}{l}\text { Kraft General Foods } \\
\text { International, INC. }\end{array}$ \\
\hline AB "Audejas" (production of tapestry) & 38 & 31,84 & 120 & $\begin{array}{l}\text { Natural Persons from } \\
\text { Germany and Lithuania }\end{array}$ \\
\hline $\begin{array}{l}\text { AB "Pienas" (processing of milk, } \\
\text { production of dairy products) }\end{array}$ & 70 & 12,48 & 45,6 & Local investor \\
\hline
\end{tabular}

Table 4. The largest investments during the $2^{\text {nd }}$ stage of privatization in Lithuania 1996-1998, (Lithuanian Business Information Center)

\begin{tabular}{|l|c|c|c|l|}
\hline Name of enterprise and activity & $\begin{array}{c}\text { Privatization } \\
\mathbf{\%}\end{array}$ & $\begin{array}{c}\text { Selling price } \\
\text { LTL, mln. }\end{array}$ & $\begin{array}{c}\text { Investments, } \\
\text { LTL, mln. }\end{array}$ & \multicolumn{1}{|c|}{ Investor } \\
\hline AB Lietuvos Telekomas & 60 & 2040 & 884 & Amber Teleholdings A/S \\
\hline $\begin{array}{l}\text { Klaipėda Ship Freight Stock Company } \\
\text { "Smelte்" }\end{array}$ & 89.51 & 45 & 75 & $\begin{array}{l}\text { Lithuanian Western Industry } \\
\text { Corporation }\end{array}$ \\
\hline AB Vakarų Laivų Remontas (Ship repair yard) & 92.51 & 83 & 80 & $\begin{array}{l}\text { Private company Western } \\
\text { Invest }\end{array}$ \\
\hline AB Aliejus & 70.24 & 8 & 8.048 & Local investor \\
\hline
\end{tabular}


Table 5. Privatization and FDI in Lithuania in 1992 1999. EUR mln. (Lithuanian Department of Statistics)

\begin{tabular}{|c|c|c|}
\hline Year & $\begin{array}{c}\text { Privatization } \\
(€ \text { million })\end{array}$ & FDI $(€$ million $)$ \\
\hline 1992 & 36,2 & 10 \\
\hline 1993 & 24,7 & 30 \\
\hline 1994 & 50,5 & 31 \\
\hline 1995 & 61,5 & 73 \\
\hline 1996 & 545,8 & 152 \\
\hline 1997 & 12,6 & 355 \\
\hline 1998 & 682,5 & 962 \\
\hline 1999 & 93,3 & 486 \\
\hline
\end{tabular}

Figure 5 reflect data used for calculations).

The equation for the correlation coefficient is:

$$
\rho_{x y}=\frac{\operatorname{Cov}(X, Y)}{\sigma_{x}{ }^{*} \sigma_{y}}
$$

where

$$
-1 \leq \rho_{x y} \leq 1
$$

and

$$
\operatorname{Cov}_{x, y}=\frac{1}{n} \sum_{i=1}^{n}\left(x_{i}-\mu_{x}\right)\left(y_{i}-\mu_{y}\right)
$$

It was found that the correlation coefficient between FDI and the process of privatization is 0,649 . Obtained result verifies that in Lithuania the FDI growth dependence on privatization is high. Determination coefficient indicates how reliable results are. The rsquared value can be interpreted as the proportion of the variance in $\mathrm{y}$ attributable to the variance in $\mathrm{x}$. This shows how many percents of variance in $x$ can be justified by variance in $y$. In our case determination coefficient is equal to 0.42 .

FDI and privatization in Lithuania, EUR mln.

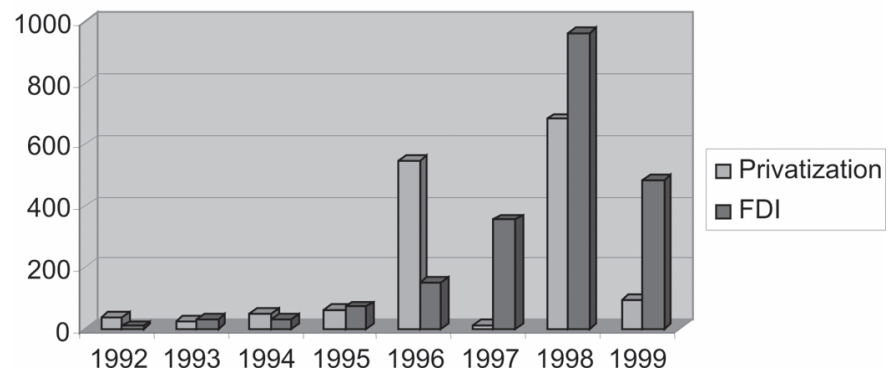

Figure 5. Privatization and FDI in Lithuania 1992-1999, EUR mln. (Lithuanian Department of Statistics)
Hence, we can claim that $42 \%$ of FDI have been caused by the process of privatization. The obtained results are consistent with economic policy of Lithuania: obvious attempts to attract capital via privatization to "strategic investor" rather than stimulate "green field" investment. The reason behind is that privatization could offer "quick money" to budget, while investment into "green field" would generate macroeconomic results only in a long - run perspective (Recall mentioned above in 1998 signed privatization contract of Lithuanian Telecom with Amber Teleholdings (consortium of Sweden "TELIA" and Finish "SORNEA").

Estonia adopted the East German model for the privatization of state companies: selling larger enterprises through a privatization agency, Eesti Erasmus, and using the State Property Department to dispose of smaller companies.

Legal grounds for privatization of large companies were established in 1992. The companies were offered for sale through public tenders, the first of which was published in late 1992. Small-scale enterprise privatization was completed by the end of 1994 . The privatization of land and residential property, by contrast, had been impeded by continuing uncertainty regarding restitution of land and slow process of land registration. In 1996 the authorities took measures to accelerate land reform by adopting legal provisions to hasten land sales.

Privatization of medium- to large-scale enterprises had a slow start but accelerated in 1996. In November 1996, the national authorities compiled a list of socalled strategic enterprises, privatization of which would have to be decided by parliament. The largest enterprises included in the list were the Tallinn Port, Estonian Telecom, airports, and energy and railways companies. The Privatization Act of 1993 allowed for sale of assets against both vouchers (up to 50 percent) and cash. The right to pay in vouchers was extended to non-residents in 1996. The voucher program was initially due to end in 1998, but was extended until the end of 2000 due to relatively late privatization of the more attractive larger companies. For privatization of land, the vouchers can be used until the end of 2001. Privatization in Estonia is regarded as virtually complete. The Estonian Privatization Agency was wound up at the end of 2001 and there are no plans to sell off the Government's remaining small shareholdings, which include the port of Tallinn and minority stakes in Estonian Telecom and Estonian Air.

In scope and pace, Estonian privatization has been a success. It is claimed, that privatized firm do not tend to fail or to reduce employment. (Nellis, 1996). 
Coming back to channels of foreign direct investment, in Estonia only $17 \%$ of FDI was received in result of privatization. Analogical as in Lithuanian case correlation analysis revealed that there is no strong relationship between FDI (data used for calculations are presented in Table 6 and Figure 6).

Hence, correlation coefficient in Estonia between FDI and privatization is 0,374 and determination coefficient equals to 0,14 . The later for Estonia is visibly lower than for Lithuania, and it implies that roughly $14 \%$ of all FDI of this country was obtained through privatization process.

Estonia with some deviation could be treated as country developing according economic rationale: the increase in GDP is consistent with the growth of FDI (Tvaronavičienè M., Ginevičius R. 2003).

Estonia also faced a significant decline of GDP in 1999. Russian crisis of 1998 represented a major external shock to Lithuanian and Estonian economies. However, Lithuania, being significantly more exposed to Russia (via trade in goods and services, investment, and financial links), suffered more than Estonia (Estonia. European Commission Report 2002).

Table 6. Privatization and FDI in Estonia in 1992 - 1999. EUR mln. (OECD Reviews of Foreign Direct Investment)

\begin{tabular}{|c|c|c|}
\hline Year & $\begin{array}{c}\text { Privatization } \\
(€ \text { million })\end{array}$ & FDI $(€$ million $)$ \\
\hline 1992 & 35 & - \\
\hline 1993 & 21,9 & 132 \\
\hline 1994 & 50,9 & 178 \\
\hline 1995 & 77,8 & 146 \\
\hline 1996 & 39,6 & 85 \\
\hline 1997 & 172 & 114 \\
\hline 1998 & 141,9 & 511 \\
\hline 1999 & 185,9 & 205 \\
\hline
\end{tabular}

FDI and privatization in Estonia, EUR mIn .

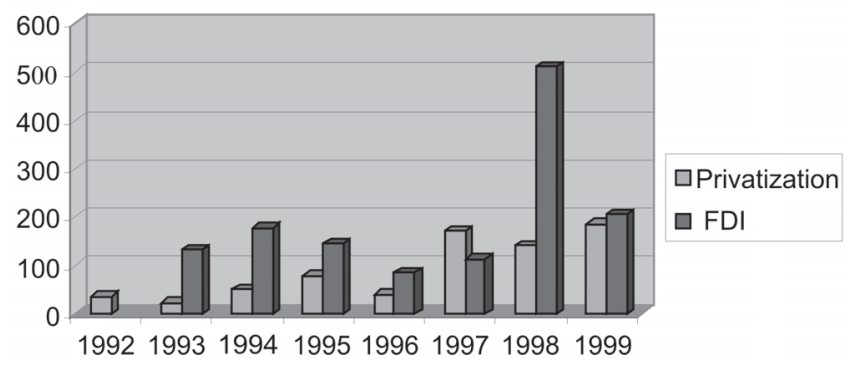

Figure 6. Privatization and FDI in Estonia 1992-1999, EUR mln. (OECD Reviews of Foreign Direct Investment
To conclude, Estonia was more successful during its transition period than Lithuania (Figure 7 illustrates the vantage of Estonia).

\subsection{Outward FDI}

In previous chapters we presented statistical data on Lithuanian and Estonian FDI. Although those Baltic States belong to same geographical area and have reach rather similar level of economic development, their outward FDI fifer considerably, as Lithuanian outward investment are particularly low (recall Figure 1). Different explanations could be found. One assumption is that incentive to invest into developed countries is suppressed as profit margin in emerging markets is much higher. Naturally, higher returns are consistent with adequate risk. Main Lithuanian investments could be listed :acquisition of $93.9 \%$ of Tallinna Külmhoone by the Lithuanian company Kauno Pieno Centras; purchase of the Paljassaare fish processing plant by the fish processing company Viciunai; and entering of Lithuanian retail chain stores Vilniaus Prekyba into Estonian market. (Lithuanian Development Agency).

Estonian's outward FDI compared to Lithuanian ones is significantly higher (Recall Figure 3). Estonian outward FDI can be attributed to two categories according their origin: Estonian companies investing abroad, and indirect outward investments trough Estonia.

The outward FDI from Estonia and most other CEE (post-socialist) countries appears to be more "pulled" by external factors (environment) than pushed by investors' firm-specific advantages. Estonia began the outward internalization (through FDI) early than large countries because of its small local market. After first successful years at home, the Estonian companies started to look for gaining economies of size and scope. More significant Estonian outward investment was recorded in 1996. In 1997 even bigger increase followed. In 1998, a heavy fluctuation and stagnation of outward FDI took place.

Until the August of 1998, the locally owned Estonian companies comprised the majority of Estonian outward investors. Afterwards, especially starting from 1999, the of Estonian outward investors were replaced by foreign ones. The Estonian direct outward FDI projects were transformed into indirect ones.

The foreign investors, in principle, choose the indirect way when a particular country ("indirect investing/ home country") has certain specific advantages as a springboard for investment to some other countries or 


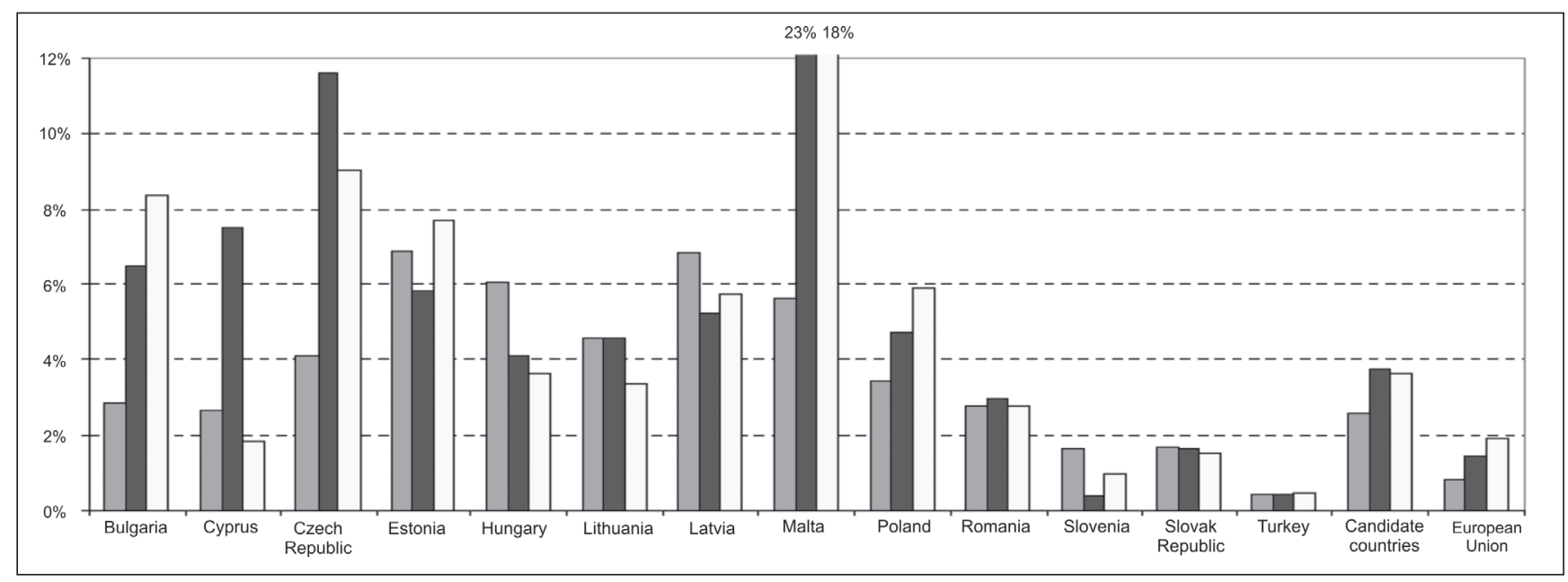

Figure 7. Inward FDI flows as It of GDP at market prices (Varblane U., et al, 2001)

regions ("preferential host countries"). Estonia has advantages as a base for investing into the other Baltic countries and probably also into some of the successor states of the former Soviet Union (Kivits K., Purju A., 2003).

According to the survey of Tartu university of Estonia, 65 percent of the Estonian companies investing abroad are indirect investors, i.e. they belong at least partially to foreign owners. Around 82 per cent of such companies have stockholders in the EU countries (Fig. 8). This implies that European companies often enter the Estonian market with the aim to expand to the other Baltic markets. In this respect the most active are Finnish and Swedish investors, who dominate in Estonia. (Varblane U. et al, 2001).

After financial crises in Russia in August 1998, the Swedish commercial banks activated in Estonia. The Swedish commercial bank Swedbank acquired the majority of shares of Hansapank and in 1999 the Skandinaviska Enskilda Banken (SEB) acquired the majority of shares of Eesti Ühispank (Union Bank of Estonia). The target of those bids was already created Baltic network.

However, later those Swedish banks have applied different outward investment strategy in increasing

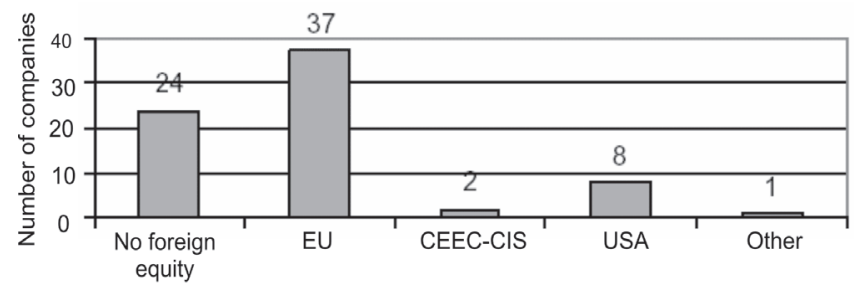

Figure 8. Origin of foreign equities in companies making OFDIs from Estonia (Varblane U. et al, 2001) their market shares in Latvia and Lithuania. The Swedbank used already acquired by Hansapank institutions in Latvia and Lithuania, started to be a major share owner, but let the institutions operate under their own names. The $S E B$, on the other hand, applied more centralized approach and changed the banking institutions in the Baltic States into local subsidiaries of the SEB.

The most important target market for Estonian investments is Lithuanian one. Number of Estonian investors in Lithuania was 103 in 2000, 130 in 2001 and 159 in 2002. Share of Estonia in Lithuanian inward FDI flow was $6.4 \%$ in $2000,10.0 \%$ in 2001 and $11.7 \%$ in 2002 .

The first place of Lithuania in Estonian outward FDI list is a result of two major investments, which together formed $90 \%$ of 2001 FDI outflow to Lithuania: the acquisition of Taupomasis Bankas by Estonian Hansapank and the Klaipeda Ship-repairing factory by the BSR Group from Estonia.

Hansapank was founded in 1991 as a private commercial bank. The internalization of Hansapank (Svetlicic and Rojec 2003; Bank of Estonia 2003) began in 1996 by the acquisition of 100 per cent of Deutsch Lettische Bank in Latvia. In July 1998, further expansion of Hansapank occurred inside Estonia by merging with Hoiupank (Savings Bank).

As a consequence, Hansapank got a subsidiary in Latvia - Zemes Banka, which was merged by Hansabank-Latvia in 1998. Since August 1998, Hansapank has had a strategic partner in the form of Förenings Sparbanken AB (Swedbank), who holds $60.1 \%$ of Hansapank's share capital.

In 1999 Swedish bank Swedbank acquired the majority of shares of Hansapank (Hansabank). In July 1999, 
Hansapank started operations in Lithuania by establishing Hansabankas. More serious entry into the Lithuanian market was made in 2001 by acquisition of Lietuvos Taupomasis Bankas (Lithuanian Savings Bank). Hansapank purchased $90.7 \%$ of the share capital of Lithuanian Savings Bank for EUR 43 million. In addition, Hansapank took an obligation to invest within the next 18 months another EUR 43 million into Lithuanian Savings Bank. In summer of 2001, Hansabank Group acquired shares from small investors and in September 2001, 0wned 99.7\% of shares. The market share of Hansabank Group consists of $32 \%$ total assets, $36 \%$ of deposits and $48 \%$ of personal deposits in the Baltic financial market. As a result of active internalization, the Hansabank Group is the largest financial institution in the Baltic countries Union (Kivits K., Purju A., 2003).

Considering the presented situation, the following conjecture arises: the North European countries (mostly Sweden and Finland) are inclined to invest indirectly through Estonia. The target of such actions usually is Baltic States and some other ex - Soviet countries. The causes of such behavior may be considered as follows. Estonia is the neighboring country and their bilateral relations have traditionally been very good and especially close in the area of economic affairs. The relations between Estonia and Finland are characterized by strong historic ties. Estonia, Finland and Sweden are all Nordic countries, so the mentality, traditions, culture and finally the manner of management might be similar. For listed reasons and, obviously, because of gained credibility Estonia has intermediated transferring capital flows of northern neighbors. Estonia managed to achieve a higher level of economic development compared to Latvia and Lithuania, where it channels investments of developed countries.

\section{Conclusions}

Although Lithuania and Estonia are perceived as similar transition countries belonging to the same economic area and having same path of economic development, FDI inflows and outflows in those countries differ significantly.

The main factor influencing growth of foreign direct investment in Lithuania was privatization. Privatization policy play a crucial role in determining the future efficiency of FDI. Intuition is that in case when transition country allows the investor to occupy and maintain monopolistic positions, FDI does not play role of economic growth accelerator. It is supposed, that due to different privatization policies
Lithuania and Estonia experienced different efficiency of FDI inflows.

Due to liberal economic policy, closeness to Finland and Sweden, Estonia better succeeded in attracting FDI. Even more, Estonia has started to perform a role of intermediator in the process of FDI channeling. Lithuania has benn targeted especially. It could be claimed, that inward FDI into Estonia caused outward FDI. There has been traced that European companies enter the Estonian market with the aim to expand into the neighbor markets. In this respect the most active are Finnish and Swedish investors, who dominate in Estonia.

Presented analysis could be treated as empirical evidence, of obvious impact of different intercultural ties and different state economic policies on process of economic development of especially similar transition countries.

\section{References}

Kivits, K.; Purju, A. Estonian Outward Foreign Direct Investments: Sources, Structure and Targets. Tallinn University of Technology, Working paper, 2003.

Nellis, J. Finding Real Owners-Lessons from Estonia's Privatization Program. Public policy for the private sector. The World Bank, January 1996, Note No 66. h t t p : / / r u.worldbank.org/Document s / PublicPolicyJournal/066nellis.pdf

Tvaronavičienè, M.; Ginevičius, R. What Drives Foreign Direct Investments into Baltic Countries? The Case of Lithuania, Latvia and Estonia. Business: Theory and Practice, 2003, Vol IV, No 4, p. 155-162.

Tvaronavičienė, M.; Kalašinskaite, K. Tiesioginių užsienio investiciju efektyvumo i̇vertinimas Baltijos šalyse. Verslas: teorija ir praktika, IV tomas, Nr. 3, 2003, p. 129-141.

Varblane, U.; Roolaht, T.; Reiljan, E.; Juriado, R. Estonian Outward Foreign Direct Investmnts. University of Tartu, 2001. 17 p.

[1] Organization for Economic Co-operation and Development. Statistics. <http://www.oecd.org/>

Advantage Lithuania, Lithuanian development agency. Reasons to invest in Lithuania. <http://www.lda.lt/ invest.reasons.html>

Lithuanian Department of Statistics. Economy and Finance. $<$ http://www.std.lt/web/main.php?parent=365>

United Nations Conference on Trade and Development. Foreign Direct Investment database. <http:// www.unctad.org/Templates>

Bank of Estonia <www. Bankofestonia.info/pub/en>

Lithuanian State Property Fund, <http://www.vtf.lt $>$

Lithuanian Business Information Center <http:// www.lbic.lt> 
Lithuanian Development Agency, http://www.lda.lt

European Commission Report 2002 (Estonia) <http:// www.fifoost.org/estland/EU_Estonia_2002/ node28.php>

OECD Reviews of Foreign Direct Investment http:// www.investinestonia.com/pdf/OECDReviewFDIEstonia.pdf

Privatization in Baltic States (interview). The Baltic course. Spring, 2000, No.1 http:/www.baltkurs.com/english/ archive/01/privat.htm 